\title{
PENEGAKAN HUKUM TERHADAP TINDAK PIDANA KEPABEANAN ATAS \\ IMPLIKASI PENYELUNDUPAN BARANG EKSPOR DIHUBUNGKAN DENGAN UNDANG-UNDANG NO 17 TAHUN 2006 TENTANG KEPABEANAN
}

\author{
oleh: \\ Suhendar Herdiyansyah \\ Cecep Sutrisna
}

\begin{abstract}
ABSTRAK
Undang-undang Dasar Negara Republik Indonesia Tahun 1945 Pasal 1 ayat (3) yang menyatakan bahwa, "Indonesia adalah Negara Hukum". Dalam konsep Negara hukum, maka setiap yang berkaitan dengan proses-proses penyelenggaraan aspek kekuasaan pemerintah didasarkan kepada hukum, termasuk dalam proses penegakan hukum dalam perkara pidana di bidang kepabeanan khususnya bidang ekspor. Kegiatan ekspor menjadi faktor utama dalam pendapatan negara, tetapi hal itu menjadi permasalahan dikarenakan adanya kejahatan berupa penyelundupan. Maka pada penelitian ini penulis akan mengangkat beberapa permasalahan hukum, yaitu; pertama, Mengenai faktor-faktor adanya tindak pidana penyelundupan; kedua, Penegakan hukum terhadap tindak pidana penyelundupan dibidang ekspor. Dari semua permasalahan tersebut akan penulis angkat sebagai penelitian skripsi ini. Tindak pidana penyelundupan di bidang hukum kepabeanan di pengaruhi oleh faktor-faktor yang saling mempunyai hubungan kausal. Faktor-faktor yang mendorong Tindak Pidana Penyelundupan adalah faktor regulasi; masyarakat; pengawasan dan penindakan. Dari semua faktor tersebut tentunya penelitian ini berhubungan dengan teori kriminologi dan efektivitas hukum. Penegakan Hukum dalam Tindak Pidana Penyelundupan di bidang ekspor secara regulasi diatur dalam Undang-Undang No. 17 Tahun 2006 tentang Kepabeanan Pasal 102A, didalamnya terdapat unsur-unsur yang dapat dikategorikan sebagai penyelundupan dibidang ekspor, tidak hanya itu Instansi Bea dan Cukai memiliki Kewenangan yang bersifat independen terhadap pengawasan dan penindakan dalam penegakan hukum di bidang pabean. Diantara Undang-Undang No.10 Tahun 1995 ataupun Undang-Undang No.17 Tahun 2006 di dalam kedua Undang-Undang tersebut berisi substansi-substansi dan Pasal-Pasal untuk memperkuat hukum pabean. Seperti kewenangan petugas Bea dan Cukai terkait penyidikan tertuang pada pasal Pasal 74 dan Pasal 112; pengawasan dan kewenangan penindakan juga terdapat pada Pasal 74 - Pasal 92 dan Pasal 64A - Pasal 90 Undang-Undang Kepabeanan. Semua peraturan tentang kepabeanan sejauh ini cukup untuk melakukan upaya penegakan hukum secara optimal.
\end{abstract}

Kata Kunci : Tindak Pidana Penyelundupan Dibidang Ekspor 


\section{PENDAHULUAN}

\section{Latar Belakang}

Pemerintah melakukan upaya untuk mendorong laju perdagangan internasional dengan berbagai bentuk insentif dan kebijakan telah banyak dilakukan, antara lain seperti terlihat pada rangkaian kebijakan. Dibidang moneter pemerintah telah pula mengeluarkan kebijakan agar mata uang rupiah tetap stabil dan meningkat dikaitkan dengan pengembangan industri dalam negeri. Sumber daya alam yang dimiliki pemerintah mempunyai nilai materil dan immateril, oleh karena itu Indonesia harus mengelolanya secara profesional dan efisien sehingga membawa manfaat besar bagi masyarakat, negara, ataupun pelaku bisnisnya.

Pasal 23 ayat (1) Undang - Undang 1945 yang berisi :

"Anggaran pendapatan dan belanja Negara sebagai wujud dari pengelolaan keuangan Negara ditetapkan setiap tahun dengan Undang-undang dan dilaksanakan secara terbuka dan bertanggung jawab untuk sebesar-besarnya kemakmuran rakyat”.

Peningkatan ekspor produk Indonesia yang dapat mengoptimalkan sumber daya alam maupun industri kreatif sehingga dapat memproduksi barang jadi dan bernilai produk-produk andalan yang mampu bersaing dipasaran internasional.

Hukum pabean sebagaimana yang telah diuraikan dalam Undang-Undang No.17 Tahun 2006 tentang Keupabeanan penjelasannya memiliki ciri yang tidak jauh sebagai bagian dari hukum fiskal. Orientasi pengaturan undang-undang kepabeanan, di samping mengatur norma-norma yang berkaitan dengan pemungutan bea masuk dan bea keluar juga mengatur norma-norma yang berkaitan dengan pengawasan lalu lintas barang yang di masukkan dan di keluarkan dari daerah pabean sehingga disamping mengatur hal-hal yang berkaitan dengan fiskal, sekaligus mengatur hal-hal di luar fiskal. Untuk kepentingan keterpaduan, dua orientasi tersebut di atur dalam sebuah sistem yang di sebut sistem hukum di bidang Kepabeanan.

Eksistensi UU Kepabeanan, telah mengatur ketentuan tentang memasukkan barang kedalam daerah pabean termasuk sanksi pidana yang melekat atas perbuatan pidana kepabeanan, akan tetapi tidak dapat membuat surut para pelaku penyelundupan (memasukkan barang ke daerah pabean secara ilegal). Hal ini menimbulkan kerusakan sistem perekonomian negara yang sudah digagas dan di rancang sebaik mungkin. Jika dilihat dari perbuatan hukum, pelaku penyelundupan dapat melakukan berbagai macam penyelundupan dan modus operandinya dari penyelundupan yang dapat masuk dalam kategori gerugian materiil ataupun immaterial.

Tindak pidana kepabenan merupakan tindak pidana berupa pelanggaran terhadap aturan hukum di bidang kepabeanan. Salah satu bentuk tindak pidana kepabeanan yang paling terkenal adalah tindak pidana penyelundupan. Sumber hukum tindak pidana kepabeanan adalah dari pada Undang-Undang itu sendiri yaitu UU Kepabeanan. Tindak pidana penyelundupan terhadap barang ekspor juga merupakan masalah yang akan menjadi bahan pembicaraan yang menarik dikalangan para penegak hukum, oleh karena itu masalah ini menjadi salah satu sasaran pokok dalam pelaksanaan tugas para penegak hukum dan beberapa instansi terkait yang memiliki kewenangan dalam hal pengawasan dan juga penindakan atas pelaksanaan barang ekspor.

Fenomena kejahatan kepabeanan khususnya penyelundupan barang ekspor merupakan kejahatan yang harus ditanggulangi dengan serius, khususnya oleh instansi terkait yang dalam hal ini adalah Direktorat Jenderal Bea dan Cukai melalui kantor-kantor wilayah maupun kantor-kantor pelayanannya yang tersebar di berbagai daerah di wilayah NKRI dengan membentuk bagian atau unit-unit khusus untuk menangani kasus kejahatan kepabeanan yang bertanggung jawab terhadap tugas-tugas penegakan hukum berkaitan tindak pidana kepabeanan. 
Latar belakang masalah dari uraian diatas mempunyai hubungan dengan contoh kasus di bawah ini seperti pada contoh kasus I : Bahwa terdakwa Ikhsan bin Umar selaku nahkoda Km.Sepakat pada hari Selasa tanggal 21 Oktober 2014 sekira pukul 05.45 WIB, bertempat di perairan Pulau Takong Kodya Batam Provinsi Kepulauan Riau pada posisi koordinat $01^{\circ}-07$ - 50" U/103- 43 - 56" T yang merupakan Wilayah Perairan Republik Indonesia atau setidak-tidaknya pada tempat yang masih termasuk daerah hukum Pengadilan Negeri Batam, namun berdasarkan Pasal 84 ayat (2) KUHAP karena terdakwa ditahan di Rumah Tahanan Negara Tanjung Balai Karimun, serta sebagian besar saksi-saksi yang dipanggil berada lebih dekat dengan Pengadilan Negeri Tanjung Balai Karimun dari pada Pengadilan dimana tindak pidana tersebut dilakukan oleh terdakwa, maka Pengadilan Negeri Tanjung Balai Karimun yang berwenang memeriksa dan mengadili perkaranya, telah melakukan perbuatan :

Mengangkut barang ekspor tanpa dilindungi dengan dokumen yang sah sesuai dengan pemberitahuan pabean sebagaimana dimaksud dalam Pasal $9 A$ ayat (1) berupa \pm 5.000 (lima ribu) batang kayu teki/bakau'. Maka Hakim mengadili terdakwa dengan Pasal 102A huruf (a) jo. Pasal 109 ayat (2) Undang-Undang Nomor 17 Tahun 2006 tentang Perubahan atas Undang-Undang Nomor 10 Tahun 1995 tentang Kepabeanan, UndangUndang Nomor 8 Tahun 1981 tentang KUHAP dan Undang-Undang Nomor 48 Tahun 2009 tentang Kekuasaan Kehakiman beserta peraturan perundang-undangan lainnya yang bersangkutan dan menjatuhkan pidana sebagai berikut :

Menjatuhkan Pidana terhadap Terdakwa dengan Pidana Penjara selama 2 (dua) Tahun dan Pidana Denda sebesar Rp. 50.000.000,- (lima puluh juta rupiah).

Contoh kasus II : Menyatakan Terdakwa Udin bin Madi telah bersalah melakukan tindak pidana :

Mengangkut barang ekspor tanpa dilindungi dengan dokumen yang sah yaitu berupa kayu ebony sebanyak 1006 (seribu enam) batang sebagaimana diatur dan diancam pidana dalam Pasal 102A huruf (a) dan (e) Undang-undang RI Nomor 17 Tahun 2006 tentang Perubahan atas Undang-Undang Nomor 10 Tahun 1995 tentang Kepabeanan.

Hakim menjatuhkan Menyatakan Terdakwa Udin bin Madi telah terbukti secara sah dan menyakinkan bersalah melakukan tindak pidana "Penyelundupan dibidang ekspor" Menjatuhkan pidana kepada Terdakwa Udin bin Madi oleh karena itu dengan pidana penjara selama 1 Tahun dan 5 Bulan serta pidana denda sebesar Rp.50.000.000,- (lima puluh juta rupiah).

Sekilas mengenai contoh kasus diatas, maka penulis memberikan asumsi mengenai prosedur penegakan hukum terhadap tindak pidana penyelundupan yang di laksanakan oleh Instansi Bea dan Cukai yang seharusnya apa yang ada dalam substansi UU Kepabeanan dilaksanakan dengan baik dan optimal, sehingga mempersempit ruang terhadap pelaku penyelundupan dan mencegah adanya aksi kejahatan tersebut baik secara preventif ataupun represif.

\section{Identifikasi Masalah}

1. Apa faktor-faktor yang mendorong timbulnya tindak pidana penyelundupan?

2. Bagaimanakah penegakkan hukum terhadap tindak pidana di bidang kepabeanan pada kasus penyelundupan terhadap barang ekspor dihubungkan dengan Undang-Undang Nomor 17 Tahun 2006 tentang Perubahan Atas Undang-Undang Nomor 10 Tahun 1995 tentang Kepabeanan? 


\section{TINJAUAN PUSTAKA}

Pasal 1 ayat (3) Undang-undang Dasar Negara Republik Indonesia tahun 1945, menyebutkan bahwa "Indonesia adalah Negara hukum". Dalam konsep Negara hukum, maka setiap yang berkaitan dengan proses penyelenggaraan aspek kekuasaan pemerintah didasarkan kepada hukum, termasuk dalam proses penegakan hukum dalam perkara pidana. Hukum pidana adalah sebagai tonggak penegak kepastian hukum dan kebenaran hukum bagi para subyek hukum.

Hukum pidana merupakan bagian dari rantai atau cabang ranting dari pada keseluruhan hukum yang berlaku di suatu Negara, yang mengadakan dasar - dasar dan aturan - aturan untuk ${ }^{1)}$ :

1. Menentukan perbuatan - perbuatan mana yang tidak boleh dilakukan, yang dilarang dan disertai dengan ancaman dan atau sanksi pidana tertentu bagi siapa saja yang melanggarnya.

2. Menentukan kapan dan dalam hal apa kepada mereka yang telah melakukan larangan - larangan itu dapat dikenakan atau di jatuhi pidana sebagaimana yang telah diancamkan.

3. Menentukan dengan cara bagaimana pengenaan pidana itu dapat dilaksanakan apabila orang yang di duga telah melanggar ketentuan tersebut.

Paragraf sebelumnya penulis berbicara teori hukum pidana yang mana hukum pidana di negara manapun berlaku dan bersifat memaksa. Pada bab selanjutya penulis mengemukakan teori tentang di berlakukannya tujuan hukum untuk masyarakat, agar masyarakat senantiasa hidup secara kondusif dan saling menghargai.

Tujuan hukum terdapat beberapa teori yang menjadi tolak ukur hukum nasional, salah satunya yang akan di kemukakan oleh para pakar hukum tentang tujuan hukum adalah pada teori pengayoman. Suatu peristiwa pentng dalam proses pembinaan hukum nasional, adalah ditemukannya lambang keadilan yang serasi dengan kepribadian bangsa kita oleh Menteri Kehakiman Sahardjo berupa pohon beringin sebagai lambang pengayoman. Lambang pengayoman ini maksudkan guna menggantikan symbol keadilan Negara Barat yang dirupakan oleh Dewi Themis (puteri Ouranos dan Gala) sebagai Dewi Keadilan ${ }^{2}$.

Pemikiran secara logika memang suatu kemustahilan seorang dewi cantik dalam kondisi mata tertutup karena dibalut kain hitam, tangan kiri memegang sebuah pedang, dan tangan kanan memegnf sebuah dacin mampu menegakkan keadilan. Barangkali alasan itulah yang menyebabkan di Negara Indonesia Lambang Dewi Keadilan di ganti oleh lambang pengayoman.

Menurut teori pengayoman tujuan hukum adalah untuk mengayomi manusia baik secara aktif maupun secara pasif. Secara aktif dimaksudkan sebagai upaya untuk menciptakan suatu kondisi kemasyarakatan yang manusiawi dalam proses yang berlangsung secara wajar. Sedangkan yang dimaksudkan secara pasif, adalah mengupayakan pencegahan atas tindakan yang sewenang-wenang dan penyalahgunaan hak. Oleh karena itu, usaha mewujudkan pengayoman tersebut termasuk di dalamnya adalah :

1. Mewujudkan ketertiban dan keteraturan;

2. Mewujudkan kedamaian sejati;

3. Mewujudkan keadilan;

\footnotetext{
${ }^{1}$ Martiman Prodjohamidjojo, Memahami Dasar-Dasar Hukum Pidana Indonesia Jilid I, Pradnya Paramita, Jakarta. 1997, hlm. 13

${ }^{2}$ Kamus Istilah Hukum, Cetakan VII, Citra Umbara ; Bandung, 2013 hlm. 92.
} 


\section{Mewujudkan kesejahteraan dan keadilan sosial3).}

Ketentuan hukum dibidang kepabeanan meliputi himpunan norma yang dituangkan dalam Undang-Undang yang mengatur pengawasan lalu lintas barang ekpor dan impor dan pungutan bea masuk atau keluar. Indonesia sendiri dengan penduduk yang sebagian besar mendapatkan penghasilan dari berdagang. Istilah perdagangan di Indonesia telah lama di perkenalkan sejak dari masa dahulu yang di tunjukkan oleh banyaknya peninggalan sejarah yang membuktikan bahwa bangsa Indonesia memang lahir juga dari perdagangan. Dahulu selat malaka telah disebut sebagai pusat perdagangan di wilayah Indonesia. Kegiatan dagang yang di lakukan oleh bangsa Indonesia tidak hanya antar wilayah, tetapi antar negara yang masih berlangsung hingga sekarang.

Perdagangan Internasional merupakan bagian kegiatan ekspor yang artinya adalah sistem perdagangan dengan cara mengelauarkan barangbarang dari dalam negeri keluar negeri dengan memenuhi ketentuan yang berlaku. Ekspor merupakan total barang dan jasa yang dijual oleh sebuah negara ke negara lain, termasuk diantara barang-barang, asuransi, dan jasajasa pada suatu tahun tertentu ${ }^{4}$.

Ekspor adalah kegiatan mengeluarkan barang dari dalam ke luar daerah pabean berdasarkan Undang-Undang No.7 Tahun 2014 Tentang Perdagangan. Dengan peraturan tersebut tentang perdagangan tentunya akan selaras dalam perdagangan Internasional yang mentaati peraturan sistem kepabeanan. Kegiatan Ekspor tentunya akan berkaitan erat dengan pajak bea keluar yang di pungut oleh pihak bea cukai dan itu merupakan kewenangannya, pemungutan tersebut dilakukan karena untuk pemasukan kas dalam negara berdasarkan aturan Undang-undang yang berlaku yaitu undang-undang perpajakan

Pajak adalah iuran rakyat kepada kas Negara bedasarkan undang-undang (yang dapat dipaksakan dengan tidak mendapat jasa timbal balik (kontraprestasi) yang langsung dapat ditunjukkan dan yang digunakan untuk membayar pengeluaran umum ${ }^{5}$. Untuk mengetahui dasar pengertian tentang kepabeanan maka, pada Pasal 1 Angka (1) UU Kepabeanan yang menyatakan bahwa Kepabeanan adalah segala sesuatu yang berhubungan dengan pengawasan atas lalu lintas barang yang masuk atau keluar daerah pabean serta pungutan bea masuk dan bea keluar.

Hukum pabean sebagai sistem yang memiliki Prinsip umum sistem hukum adalah rangkaian subsistem yang bekerja secarafungsional yang bergerak secara terpadu mencapai tujuan sistem hukum pabean. Dalam kapasitas sebagai aturan fungsional yang bergerak secara terpadu, gerakan tersebut tertuju kearah akuntabilitas di bidang hukum. Berbicara masalah akuntabilitas tidak hanya terkait dengan masalah tanggung jawab individual tetapi juga tanggung jawab institusional.

Rekosntruksi sistem hukum dibidang kepabeanan perlu dilakukan agar sistem hukum kepabeanan lebih mendapat kepecayaan dan respek masyarakat. Oleh karena itu, sebagai sebuah sistem harus terbuka dan transparan sehingga akuntabiitas sistem hukum kepabeanan merupakan bagian konsep pemerintahan yang baik. Menurut H.Theierry sistem artinya, sebuah sistem adalah keseluruhan bagian yang saling mempengaruhi satu sama lainnya menurut suatu rencana yang telah ditentukan, untuk mencapai suatu tujuan tertentu.

Pengertian sistem menurut William A shourde/Dan Voich Jr. sebuah sistem adalah seperangkat bagian yang saling berhubungan, bekerja di bebas dalam mengejar keseluruhan tujuan dengan kesatuan lingkungan ${ }^{6}$. Definisi dari pengertian tersebut diatas, dapat

${ }^{3}$ D. Duswara Machmudin, Pengantar Ilmu Hukum Sebuah Sketsa, Cetakan. V, PT. Refika Aditama, Bandung, 2013, hlm. 28.

${ }^{4}$ Hamdani, Buku Ekspor - Impor Tinkat Dasar. Cetakan III, Bushindo, Jakarta 2017, hlm. 5

${ }^{5}$ Waluyo, Perpajakan Indonesia, Salemba Empat, Cetakan II, Jakarta, 2007, hlm. 3.

${ }^{6}$ Bachsan Mustafa, Sistem Hukum Indonesia Terpadu, Citra Aditya Bhakti, Bandung, 2003, hlm.4 
diidentifikasi faktor - faktor yang terkandung dalam sistem tersebut, yakni :

1. Faktor komponen atau bagian;

2. Masing - masing faktor saling memengaruhi dan berhubungan

3. Masing - masing faktor bekerja sedikit bebas ;

4. Terdapat rencana;

5. Pencapaian tujuan

Penegakan hukum pada prinsipnya harus dapat memberi manfaat atau berdaya guna (utility) bagi masyarakat, namun di samping itu masyarakat juga mengharapkan adanya penegakan hukum untuk mencapai suatu keadilan. Kendatipun demikian tidak dapat kita pungkiri, bahwa apa yang dianggap berguna (secara sosiologis) belum tentu adil, begitu juga sebaliknya apa yang dirasakan adil (secara filosofis), belum tentu berguna bagi masyarakat.

PPNS atau dikatakan penyidik pegawai negeri sipil dalam hal ini bea cukai, memiliki kewenangan dalam melakukan tindakan pengawasan, pemeriksaan dan juga penangkapan terhadap pelaku tindak pidana di bidang kepabeanan. Hal ini merupakan merupakan upaya dalam penegakan hukum, agar aturan hukum dapat berjalan secara optimal dengan tidak mengganggu aparat penegak hukum dalam menjalankan kewajibannya, berdasarkan Pasal 1 angka (5) PP No.43 Tahun 2012 tentang Tata Cara Pelaksanaan, Koordinasi Pengawasan dan Pembinaan Teknis Terhadap Kepolisian Khusus, Penyidik Pegawai Negeri Sipil, dan Bentukbentuk Pengamanan Swakarsa.

Penegakan hukum adalah upaya aparat penegak hukum untuk menjamin kepastian hukum, ketertiban dan perlindungan hukum pada era modernisasi dan globalisasi saat ini dapat terlaksana, apabila berbagai dimensi kehidupan hukum selalu menjaga keselarasan, keseimbangan dan keserasian antara moralitas sipil yang didasarkan oleh nilai-nilai aktual di dalam masyarakat beradab. Sebagai suatu proses kegiatan yang meliputi berbagai pihak termasuk masyarakat dalam kerangka pencapaian tujuan, adalah keharusan untuk melihat penegakan hukum pidana sebagai sistem peradilan pidana $^{7}$.

Penegakan hukum sendiri, diartikan dalam kerangka tiga konsep, yaitu:

1. Konsep penegakan hukum yang bersifat total (total enforcement concept) yang menuntut agar semua nilai yang ada dibelakang norma hukum tersebut ditegakkan tanpa terkecuali.

2. Konsep penegakan hukum yang bersifat penuh (full enforcement concept) yang menyadari bahwa konsep total perlu dibatasi dengan hukum acara dan sebagainya demi perlindungan kepentingan individual.

3. Konsep penegakan hukum aktual (actual enforcement concept) yang muncul setelah diyakini adanya diskresi dalam penegakan hukum karena keterbatasan - keterbatasan, baik yang berkaitan dengan sarana, kualitas sumber daya manusianya, perundang-undangannya dan kurangnya partisipasi masyarakat ${ }^{8}$.

Penegakan hukum idealnya selaras berjalan baik terhadap penguakan kasus-kasus tindak pidana khususnya di bidang kepabeanan yang pada hakikatnya kasus-kasus di bidang kepabeanan menganggu stabilitas perekonomian negara, seperti penyelundupan, pemalsuan dokumen dan sebagainya. Kasus penyelundupan saat ini sudah masuk pada taraf yang memprihatinkan, karena terjadi untuk semua komoditas, mulai dari penyelundupan mobil, elektronik, kayu, hingga satwa liar. Penyelundupan dalam menjadi kasus yang cukup merugikan Negara. Sumber daya alam hayati tersebut merupakan salah satu modal dasar dan sekaligus sebagai faktor dominan yang perlu diperhatikan dalam pembangunan nasional untuk

\footnotetext{
${ }^{7}$ Sukarton Marmoesudjono, Penegakan Hukum di Negara Pancasila, Jakarta; Pustaka Kartini, 1989, hlm. 81

8 Ibid,. hlm. 76
} 
mewujudkan masyarakat adil dan makmur berdasarkan Pancasila dan Undang-Undang Dasar 1945.

Tindak pidana penyelundupan barang ekspor ini tentu saja sangat merugikan pemerintah dari segi pendapatan negara maupun sangat meresahkan masyarakat dari segi stabilitas ekonomi pada saat sekarang. Mengingat tindak pidana penyelundupan tersebut adakalanya dapat diketahui oleh aparat, akan tetapi pelakunya tidak tertangkap, maka kenyataan ini juga semakin menggelisahkan masyarakat.

Perbuatan penyelundupan ini menimbulkan pengaruh yang sangat negatif terhadap beberapa segi dalam kelangsungan hidup bangsa dan negara, baik secara langsung yang mengakibatkan kerugian dalam penerimaan negara dari bea masuk serta pungutan-pungutan lain yang seharusnya diterima oleh pemerintah melalui Dirjen Bea dan Cukai, maupun kerugian yang tidak langsung yaitu mengakibatkan kemacetan atau hambatan produksi dalam negeri sehingga merugikan pihak pemerintah yang memproduksinya ${ }^{9}$.

Penyelundupan yang pengertiannya disejajarkan dengan smuggling (penyelundupan) dalam The Lexicon Webster Dictionary, disebutkan sebagai "to import or export secretly and contrary to law, without payment of legally requied duties" (memasukkan atau mengeluarkan barang-barang dan uang secara rahasia bertentangan dengan hukum tanpa membayar bea yang diharuskan menurut peraturan $)^{10)}$.

Tindak pidana penyelundupan merupakan kejahatan yang masuk dalam kategori kriminologi, kriminologi sendiri pada fakultas hukum di pelajari di tingkat semester 6. Ilmu kriminologi tidak hanya berbicara tentang pengertian tapi berbicara juga tentang sebab musabab terjadinya tindakan kejahatan di lingkungan kita.

Kriminologi berorientasi pada hal-hal sebagai berikut:

1. Pembuatan hukum yang dapat meliputi telaah konsep kejahatan, siapa pembuat hukum dengan faktor-faktor yang harus diperhatikan dalam pembuatan hukum.

2. Pelanggaran hukum yang dapat meliputi siapa pelakunya, mengapa sampai terjadi pelanggaran hukum tersebut, dan faktor-faktor yang mempengaruhinya.

3. Reaksi terhadap pelanggaran hukum melalui proses peradilan pidana dan reaksi masyarakat $^{11)}$.

Kriminologi sebagai perbuatan yang disebut sebagai kejahatan, pelaku kejahatan, dan reaksi yang ditunjukkan baik terhadap perbuatan maupun terhadap pelakunya. Sedangkan etiologi kriminal (criminal aetiology) adalah ilmu yang menyelidiki atau yang membahas asal-usul atau sebab-musabab kejahatan (kasus kejahatan).

Hubungan kejahatan dengan gejala social lainnya bisa dikatakan bahwa timbulnya kejahatan merupakan suatu kebiasaan atau kebebasan produk yang dihasilkan dari tingkah laku manusia.

Teori kemauan bebas (free will) menyatakan bahwa manusia itu bisa bebas menurut kemauannya, dengan kemauan bebas itu dia berhak menentukan pilihan dan sikapnya, untuk menjamin agar setiap perbuatan berdasarkan kemauan bebas itu cocok dengan keinginan masyarakat, maka manusia harus diatur dan ditekan dengan; hukum, norma-norma social dan pendidikan. Hukum dan hukuman biasanya disertai ancaman-ancaman pidana yang menakutkan, agar manusia merasa takut berbuat kejahatan dan tidak menyimpang dari kehidupan normal ${ }^{12}$.

9 Purwito M, Ali, Kepabenanan dan Cukai Lalu Lintas Barang,Konsep dan Aplikasinya, Cetakan IV, Kajian Hukum Pabean FHUI, 2010, hlm. 5

${ }^{10}$ Prapto Soepardi, Tindak Pidana Penyelundupan, Usaha Nasional; Surabaya. 1991, hlm, 36.

${ }^{11}$ Lilik Mulyadi, Bunga Rampai Hukum Pidana Umum dan Khusus, Alumni, Bandung, 2012, hlm. 36

12 Dirdjosisworo, Soedjono, Pengantar Tentang Psikologi Hukum, Bandung; Alumni, 1983, hlm 34 
Hakikatnya semua orang harus melaksanakan hukum dengan baik sesuai dengan definisi hukum itu sendiri dan bunyi norma hukum. Bagi orang-orang yang dikenai sanksi hukum, maka sanksi hukum benar-benar dilaksanakan atau tidak karena hukum memiliki prinsip yang kuat berdasarkan asas hukum yang dimiliki yaitu asas "Bahwa semua orang di anggap mengetahui hukum".

Kata efektif berasal dari bahasa Inggris yaitu effective yang berarti berhasil atau sesuatu yang dilakukan berhasil dengan baik. Kamus ilmiah populer mendefinisikan efetivitas sebagai ketepatan penggunaan, hasil guna atau menunjang tujuan. Menurut Kamus Besar Bahasa Indonesia, efektif adalah sesuatu yang ada efeknya (akibatnya, pengaruhnya, kesannya) sejak dimulai berlakunya suatu Undang-Undang atau peraturan ${ }^{13)}$.

Sedangkan efektivitas itu sendiri adalah keadaan dimana dia diperankan untuk memantau. Jika dilihat dari sudut hukum, yang dimaksud dengan "dia" disini adalah pihak yang berwenang yaitu polisi. Kata efektifitas sendiri berasal dari kata efektif, yang berarti terjadi efek atau akibat yang dikehendaki dalam suatu perbuatan. Setiap pekerjaan yang efisien berarti efektif karena dilihat dari segi hasil tujuan yang hendak dicapai atau dikehendaki dari perbuatan itu.

\section{PEMBAHASAN}

\section{Faktor-faktor Yang Mendorong Terjadinya Tindak Pidana Penyelundupan}

Faktor-faktor yang mendorong timbulnya tindak pidana penyeludupan ialah :

1. Peraturan/Regulation

Pemerintah pada saat ini telah berusaha menghilangkan birokrasi yang berbelit-belit dalam pengurusan barang-barang impor dan ekspor, Di mana salah satu kebijaksanaan pemerintah tersebut ialah dengan dikeluarkannya Instruksi Presiden (INPRES) Nomor 4 Tahun 1985 tentang Kebijaksanaan Kelancaran Arus Barang Untuk Menunjang Kegiatan Ekonomi.

\section{Masyarakat}

Kenyataan diatas, di mana kebutuhan ekonomi serta mentalitas para pelaku menjadi masalah utama dalam hukum pabean, karena para pelaku menginkan dalam segi ekonomi biaya produksi yang murah bahkan tidak mengeluarkan biaya produksi, selain itu juga paradigma regulasi yang sangat menyulitkan maka inilah yang membuat penyelundup nekat melakukan aksinya ketika niat dan kesempatan ada. Masyarakat seperti ini cenderung menyimpang dan berbuat kriminal, semua itu karena situasi sekitar yang mempengaruhi secara pesikis atau sosialis. Hal ini dapat di lihat berdasarkan teori kriminologi yaitu Differential Association pada intinya berbicara perilaku yang menyimpang yang didapatkan setelah proses belajar.

\section{Pengawasan dan Penindakan}

Pengawasan dan penindakan pabean adalah salah satu cara untuk mencegah dan mendeteksi adanya pelanggaran. Pengawasan dan penindakan yang efektif memungkinkan Intansi Bea dan Cukai mengurangi terjadinya tingkat pelanggaran yang sering terjadi. Dari berbagai tipe pelanggaran sebagian besar adalah pengimporan atau pengeksporan di pelabuhan tempat pengawasan Bea dan Cukai.

Secara teoritis bisa secara rutin dikirim satuan tugas Surveillance dari Kantor Wilayah untuk mengumpulkan dan mencari informasi ke seluruh wilayah tetapi secara teknis sulit kalau wilayahnya relatif luas. Akan lebih mudah kalau kegiatan intelijen juga dilakukan oleh Kantor Pelayanan karena mereka berada didekat sumber informasi. Pada

${ }^{13}$ Kamus Besar Bahasa Indonesia, Jakarta, Balai Pustaka, 2002, Hlm. 284 
umumnya yang dianggap informasi bagi orang awam adalah pemberitahuan dari seseorang atau badan secara tertulis atau lisan bahwa akan terjadi penyelundupan yang dilakukan oleh seseorang.

Informasi yang sudah matang ini di Bea Cukai lazim disebut hasil intelijen atau intelijen positif. Sebenarnya informasi tidak hanya sebatas yang sudah matang saja tetapi banyak informasi yang masih mentah berserakan disana-sini berada dalam dokumen Pabean maupun dokumen pelengkapnya, informasi ini kalau diolah juga akan menghasilkan informasi matang (intelijen positif) yang dapat digunakan mendeteksi penyelundupan atau pelanggaran Kepabeanan.

Tugas pencegahan, penindakan dan penyidikan yang tidak optimal ini harus dilaksanakan sesegera mungkin dengan optimal terutama oleh Kantor Wilayah. Hal ini nampak dari adanya fungsi pelaksanaan intelejen, patroli, dan operasi pencegahan pelanggaran, penindakan, serta penyidikan yang tidak dimiliki oleh Kantor Pelayanan. Bidang Pencegahan dan Penyidikan pada Kantor Wilayah diharapkan dapat melakukan terus menerus dalam bidang pencegahan penindakan dan penyidikan

Hukuman atau sanksi sanksi yang diberikan diharapkan membuat jera pelakunya sehingga dikemudian hari tidak melakukan pelanggaran lagi. Jika dilihat dari banyaknya importir/eksportir yang melakukan kegiatan tentunya tidak seluruh perusahaan diaudit. Untuk menyeleksi perusahaan mana yang perlu dilakukan audit juga diperlukan informasi dan informasi yang diperlukan ini tersedia di Kantor Pelayanan.

\section{Penegakan Hukum Terhadap Tindak Pidana Kepabeanan Atas Kejahatan Penyelundupan Di Bidang Ekspor}

Undang-undang Kepabeanan yang baru (UU No.17 Tahun 2006), terjadi fase perubahan norma pengertian penyelundupan. Jika dalam UU Pabean yang lama pengertian penyelundupan hanya jika sama sekali tidak memenuhi ketentuan, maka dalam UU baru diurai menjadi 13 norma yang dapat dikategorikan sebagai ekspor atau impor. Secara lengkap Pasal 102A UU Pabean mengatur mengenai sanksi pidana tehadap penyelundupan dibidang Ekspor, pasal tersebut pada Undang-undang kali ini memiliki kualifikasi khusus untuk ekpor. Secara lengkap Pasal 102A UUP mengatur mengenai sanksi pidana terhadap penyelundupan dibidang ekspor. Jika penulis analisa ada beberapa norma-norma pada Pasal 102A menetapkan tindakan yang dianggap sebagai penyelundupan atau yang dapat dikategorikan sebagai tindak pidana penyelundupan jika memenuhi unsur-unsur berikut, yaitu :

1. Mengangkut barang ekspor yang tidak tercantum dalam manifest;

2. Memuat atau mengangkut barang ekspor dari dalam daerah pabean ke luar daerah pabean atau tempat lain tanpa izin kepala kantor pabean;

3. Dengan sengaja memberitahukan jenis atau jumlah barang ekspor dalam pemberitahuan pabean secara salah;

4. Mengangkut barang ekspor tanpa dilindungi dokumen yang sah.

Pada dasarnya perlu diperatikan untuk dapat dikatakan sebagai telah terjadi perbuatan pidana/delik harus memenuhi unsur-unsur delik. Unsur-unsur delik ini harus memenuhi secara keseluruhan, apabila satu saja tidak memenuhi unsur tersebut maka tidak bisa dikatakan telah terjadi perbutan tindak pidana. Adapun unsur-unsur delik, yaitu:

1. Ada perbuatan yang mencocoki rumusan delik dalam undang-undang.

2. Melawan hukum dan tidak ada alasan pembenaran;

3. Ada kesalahan dan tidak ada alasan pemaafan;

4. Dilakukan oleh orang yang dapat dipertanggungjawabkan. 
Penegakan hukum di bidang pabean dalam hal pengawasan untuk pemenuhan kewajiban pabean seharusnya di laksanakan dengan baik seperti mendirikan pos pengawasan pabean agar mengurangi tingkat kejahatan seperti penyelundupan seperti apa yang tertuang dalam Pasal 5 ayat (3), dan selanjutnya terkait pengawasan dan penindakan Instansi Bea dan cukai memiliki kewenangan penuh setara dengan aparat kepolisian, serta memiliki kewenangan kerja sama dengan aparat penegak hukum lainnya. Selain itu, pengawasan dan penindakan di atur juga dalam Pasal 64A Pasal 90 UU Kepabeanan. (UU No. 17 Tahun 2006).

Instansi Bea dan Cukai memiliki kewenangan dalam melakukan segala tindakan , jika diperlukan seperti penyidikan, pengawasan dan juga penindakan. Dalam hal penyidikan, yang menjadi penyidik biasanya dalah polisi, tetapi berbeda dengan Instansi Bea dan Cukai yang memiliki kewengan sendiri dalam hal tersebut, biasanya disebut dengan PPNS (penyidik pegawai negeri sipil). Penyidik Pejabat Pegawai Negeri Sipil tertentu yang diberi wewenang khusus oleh Undang-Undang misalnya Pejabat Bea dan Cukai, Pejabat Imigrasi dan Pejabat Kehutanan, yang melakukan tugas Penyidikan sesuai dengan wewenang khusus yang diberikan oleh Undang-Undang yang menjadi dasar hukumnya masing-masing. Sebagaimana disebutkan dalam Pasal 74 dan Pasal 112 Undang-Undang No. 10 Tahun 1995 tentang Kepabeanan (sebelum dirubah).

Penegakan hukum dibidang kepabeanan merupakan hal yang paling utama yang harus dilakukan instansi Bea dan Cukai, karena instansi tersebut merupakan sistem yang tidak lepas terhadap perkembangan dan pembangunan nasional dalam hal ini tentang keuangan negara. Tidak hanya itu tugas dari pada instansi Direktorat Jendral Bea dan Cukai adalah mengamankan wilayah teritorial negara yang berada dalam kawasan ZEE dari ancaman luar negeri dan ini berlaku di segala bidang, yaitu ideology, ekonomi, social, budaya dan bidangbidang lainnya, serta yang paling penting yang sudah penulis kemukakan ialah mengamankan keungan negara. Maka pengawasan dan penindakan di bidang cukai pun harus baik dan terintegritas karena hal ini berhubungan erat dalam penegakan hukum dibidang kepabenanan yang sangat penting demi terselenggaranya visi negara dalam peningkatan di bidang ekonomi.

Melihat dari kedua contoh kasus yang telah penulis uraikan terhadap penyelundupan ekspor, pada kasus tersebut sayangnya jaksa tidak menemukan kerugian terhadap negara, karena barang yang di selundupkankan adalah kayu gelondongan, yang mana kayu tersebut memang dilarang untuk di ekspor dan tidak bisa ditaksir dari harganya karena kayu tersebut merupakan sumber daya alam yang dimiliki Indonesia yang tidak bisa dihitung harganya.

Memperhatikan Pasal-Pasal yang ada dalam peraturan Perundang-ndangan Kepabeanan, paraturan yang baru ataupun peraturan lama telah tersedia di dalamnya tentang pelaksanaanya mengenai penegakan hukum pabean. Mengenai kewenangan Instansi Kepabeanan tertuang pada Pasal 74-Pasal 92 Undang-Undang No.10 Tahun 1995, sedangkan jika penulis perhatikan pada Undang-Undang baru segala tindakan preventif ataupun represif dalam penegakan hukum pabean tertuang pada Pasal 64A-Pasal 90 Undang-Undang No.17 Tahun 2006. Dan di atur pula mengenai ketentuan pidana yang ada dalam Pasal 102-Pasal 109 baik dalam Peraturan lama ataupun peraturan yang baru, di antara Pasal tersebut disisipkan Pasal tambahan.

Segala cara telah dilakukan pemerintah dalam upaya untuk memperkecil angka penyelundupan di bidang pabean baik itu ekspor atupun impor, karena hal tersebut berkaitan dengan sistem hukum di Indonesia yang pada hakikatnya memberikan kepastian hukum. 


\section{PENUTUP}

\section{Kesimpulan}

Tindak pidana penyelundupan di Indonesia di pengaruhi oleh beberapa faktor yang saling mempunyai hubunga kausal. Faktor-faktor yang mendorong Tindak Pidana Penyelundupan adalah : Peraturan/Regulation Instruksi Presiden (INPRES) Nomor 4 Tahun 1985 tentang Kebijaksanaan Kelancaran Arus Barang Untuk Menunjang Kegiatan Ekonomi. Tetapi, sekarang dengan adanya UU Kepabeanan yang baru di harapkan memudahkan para eksportir dan importir menyampaikan invoice nya kepada instansi Bea cukai dan juga memperbaiki lagi aturan yang sudah ada agar mengurangi angka penyelundupan yang lebih besar lagi. Hal ini belom berjalan dengan intens sehingga para pelaku penyelundup menyimpang dari suatu peraturan yang telah dibuat. Masyarakat dalam usaha penaggulangan tindak pidana penyelundupan sering di rasakan kurangnya partisiapasi dan wawasan dari warga masyarakat, meskipun media masa telah cukup gencar memuat berita-berita tentang pemberantasan tindak pidana penyelundupan, mungkin hal ini disebabkan karena warga masyarakat merasa beruntung karena dapat membeli barang-barang eks luar negeri asal selundupan dengan harga murah dan mutu yang tinggi selain itu juga eksportir dapat mengekspor barang tanpa menyampaikan pemberitahuan pabean yang secara sosiologis sangat membuat eksportir malas untuk menyampaikannya dengan alasan jenjang perizinan yang sangat panjang. Penjelaan ini selaras dengan pemikiran teori kriminologi yaitu tentang teori control sosial, yang memiliki kecenderungan melakukan kejahatan yang sama, pengawasan secara umum berarti kegiatan untuk menjaga agar rencana yang telah dibuat dapat dilaksanakan dengan efektif. Pengertian ini hakikatnya sama dengan definisi Colin Vassarotti mengenai pengawasan pabean yaitu suatu kegiatan yang tujuannya memastikan semua pergerakan barang, kapal, pesawat terbang, kendaraan dan orang-orang yang melintas perbatasan negara berjalan dalam kerangka hukum, peraturan, dan prosedur pabean yang telah ditetapkan.

Salah satu agar berjalanya hukum dengan baik sesuai kaidah karena adanya peraturan, masyarakat hukum dan juga aparat penegak hukum dalam mengawasi perbuatan hukum hal ini berermin pada teori efektivitas hukum yang telah dikemukakan penulis pada bab sebelumnya. Penegakan Hukum dalam Tindak Pidana Penyelundupan di bidang ekspor secara regulasi diatur dalam ketentuan pidana pada UU Kepabeanan Pasal 102A menetapkan tindakan yang dianggap sebagai penyelundupan atau yang dapat dikategorikan sebagai tindak pidana penyelundupan jika memenuhi unsur-unsur berikut, yaitu : Adanya perbuatan yang melawan hokum. Mengankut barang ekspor yang tidak tercantum dalam manifest. Memuat atau mengangkut barang ekspor dari dalam daerah pabean ke luar daerah pabean atau tempat lain tanpa izin kepala kantor pabean; Membongkar barang ekspor di dalam daerah pabean tanpa izin kepala kantor pabean;atau Mengangkut barang ekspor tanpa dilindungi dokumen yang sah. Semua mengenai penegakan hukum termuat dalam UU Kepabeanan baik peraturan yang baru ataupun peraturan yang lama, seperti ketentuan pidana yang tertuang pada Pasal 102 - 109 UU Kepabeanan. Tidak hanya ketentuan pidana saja, ada pula mengenai tentang kewenangan petugas Bea dan Cukai seperti kewenangan terkait penyidikan (Pasal 74 dan Pasal 112 UU Kepabeanan), pengawasan dan juga tindakan-tindakan yang perlu dilakukan oleh petugas Bea dan Cukai (Pasal 74-Pasal 92 dan Pasal 64A-Pasal 90 UU Kepabeanan).

\section{Saran}

Indonesia dengan segala cara haruslah berbenah terhadap adanya tindak pidana penyelundupan dari mulai pengawasan yang ketat dan intens sampai penindakan terhadap pelaku penyelundup agar merasakan efek jera. Selain itu, pemerintah dengan regulasi yang sudah terbentuk yaitu UU Kepabeanan haruslah di implementasikan dengan baik ataupun di 
tingkatkan baik dari substansi maupun dari isi Pasal tersebut agar mempersempit ruang para pelaku penyelundup dan mempermudah eksportir maupun importir dalam penyampaian ekspor/impor barang dalam dunia perdagangan Internasional.

Kejahatan dari Hukum Kepabeanan salah satunya adalah Tindak Pidana Penyelundupan, kejahatan yang merugikan negara secara dengan Tindak Pidana Korupsi. Oleh karena itu, Instansi kepolisian,TNI dan Instansi Bea dan Cukai bagian penindakan dan pengawasan haruslah bersinergi saling membentuk satu kesatuan demi terciptanya pengawasan kepabeanan yang optimal entah itu pengawasan melalui teknologi atau pengawasan dengan cara patroli rutin atau membuat pos pabean layaknya kantor-kantor polisi pada umunya agar memperketat barang yang akan masuk ataupun keluar daerah pabean.

Terhadap penegakan hukum di bidang pabean, tentunya menjadi masalah utama menaggulangi kejahatan penyelundupan dan kejahatan lainnya yang berkaitan dengan eksporimpor. Modus operandi yang di lakukan pelaku berbagai macam, oleh karena itu petugas Bea dan Cukai harus siap mengantisipasi akan adanya penyimpangan tersebut baik secara aktif atupun pasif. UU kepabeanan sudah mengatur mengenai kewenangan petugas, pengawasan dan penindakan baik tindakan preventif ataupun tindakan represif. Dalam hal penegakan hukum, petugas Bea dan Cukai harus bersinergi dengan aparat penegak hukum lainnya, tetapi akan lebih efektif jumlah personil dari petugas Bea dan Cukai mencukupi untuk mengontrol terhadap barang masuk atau keluar sehingga mampu mencegah secara preventif.

\section{DAFTAR PUSTAKA}

Bachsan Mustafa, Sistem Hukum Indonesia Terpadu, Citra Aditya Bhakti, Bandung, 2003

Dirdjosisworo, Soedjono, Pengantar Tentang Psikologi Hukum, Bandung; Alumni, 1983

D. Duswara Machmudin, Pengantar Ilmu Hukum Sebuah Sketsa, Cetakan. V, PT. Refika Aditama, Bandung, 2013

Hamdani, Buku Ekspor - Impor Tinkat Dasar. Cetakan III, Bushindo, Jakarta 2017

Lilik Mulyadi, Bunga Rampai Hukum Pidana Umum dan Khusus, Alumni, Bandung, 2012

Martiman Prodjohamidjojo, Memahami Dasar-Dasar Hukum Pidana Indonesia Jilid I, Pradnya Paramita, Jakarta. 1997,

Prapto Soepardi, Tindak Pidana Penyelundupan, Usaha Nasional; Surabaya. 1991

Purwito M, Ali, Kepabenanan dan Cukai Lalu Lintas Barang,Konsep dan Aplikasinya, Cetakan IV, Kajian Hukum Pabean FHUI, 2010

Sukarton Marmoesudjono, Penegakan Hukum di Negara Pancasila, Jakarta; Pustaka Kartini, 1989

Waluyo, Perpajakan Indonesia, Salemba Empat, Cetakan II, Jakarta, 2007

Kamus Istilah Hukum, Cetakan VII, Citra Umbara ; Bandung, 2013.

Kamus Besar Bahasa Indonesia, Jakarta, Balai Pustaka, 2002, 